\title{
EFEKTIVITAS KOMUNIKASI PEMASARAN KAMPUNG BUDAYA SINDANGBARANG DI DESA PASIR EURIH KECAMATAN TAMANSARI KABUPATEN BOGOR
}

\section{The Effectiveness of Marketing Communication Sindangbarang Cultural Tourism in Pasir Eurih Village, Tamansari Sub-District, Bogor Regency}

\author{
Rizki Nur Fadila1), Ninuk Purnaningsih ${ }^{1)}$, dan Dwi Retno Hapsari1) \\ ${ }^{1)}$ Departemen Sains Komunikasi dan Pengembangan Masyarakat, Fakultas Ekologi Manusia, Institut \\ Pertanian Bogor, Darmaga Bogor 16680, Indonesia \\ Email: kikifadila@rocketmail.com; ninukpu@apps.ipb.ac.id; retnokpm@apps.ipb.ac.id
}

\begin{abstract}
Tourism is one of the strategic sectors of the country foreign exchange contribution. Indonesia is a rich country which has a tourism potential, cultural tourism is one of them. The growth of the tourism sector must be balanced with a good marketing communications. Marketing communication is an attempt to convey and distribute the information to the public about the existence of a product, in this case is tourist attraction. The purpose of this study is to analyze the characteristics of the visitor, forms of marketing communication used by the tourist, the impact between visitor characteristics and the effectiveness of marketing communications. This study measures about the effectiveness of marketing communications based from each three promotion tools; leaflet, hybrid media, and Words of Mouth then divided into three aspects, namely cognitive, affective, and conative.. The result of this research showed that only affective aspect is impacted in marketing communication effectivity.
\end{abstract}

Keywords: leaflet, hybrid media, Words of Mouth

\begin{abstract}
ABSTRAK
Pariwisata adalah salah satu sektor strategis sumbangan devisa negara. Indonesia adalah negara yang kaya yang memiliki potensi wisata, wisata budaya adalah salah satunya. Pertumbuhan sektor pariwisata harus seimbang dengan komunikasi pemasaran yang baik. Pemasaran komunikasi adalah upaya untuk menyampaikan dan menyebarkan informasi kepada publik tentang keberadaan suatu produk, dalam hal ini adalah objek wisata. Tujuan dari penelitian ini adalah untuk menganalisis karakteristik pengunjung, bentuk komunikasi pemasaran yang digunakan oleh turis, dampak antara karakteristik pengunjung dan efektivitas komunikasi pemasaran. Studi ini mengukur tentang efektivitas komunikasi pemasaran berdasarkan dari setiap tiga alat promosi; leaflet, media hibrida, dan kata-kata dari mulut kemudian dibagi menjadi tiga aspek, yaitu kognitif, afektif, dan konatif. Hasil penelitian ini menunjukkan bahwa hanya aspek afektif yang dipengaruhi efektifitas komunikasi pemasaran.
\end{abstract}

Kata kunci: leaflet, media hibrida, kata-kata dari mulut

\section{PENDAHULUAN}

Pariwisata merupakan kegiatan rekreasi diluar domisili untuk melepaskan diri dari pekerjaan rutin atau mencari suasana lain (Damanik dan Weber 2006). Sedangkan, menurut UU No. 10 tahun 2009 yang mengatur mengenai kepariwisataan di Indonesia, wisata adalah kegiatan perjalanan yang dilakukan oleh seseorang atau sekelompok orang. Walaupun kebutuhan berwisata bukan merupakan kebutuhan primer manusia, nampaknya hal ini tidak menyurutkan kedudukan kontribusi sektor pariwisata dalam peningkatan devisa negara. Terbukti dengan peningkatan jumlah pemasukan perjalanan wisata nusantara sejak tahun 2009 hingga 2013 sebesar 39,13 triliun (Pusdatin Kemenparekraf dan BPS) ${ }^{1}$. Salah satu bentuk

\footnotetext{
${ }^{1}$ Alamat website Kemenprarekraf http://www.parekraf.go.id/userfiles/file/B_1\%20Reka pitulasi\%20Wisnus\%202009\%20-2013(1).pdf
} 
wisata di Indonesia adalah wisata budaya. Wisata budaya berupaya melestarikan lingkungan dan budaya masyarakat setempat. Kampung Budaya Sindangbarang merupakan salah satu contoh tempat wisata edukasi budaya dan sejarah Sunda yang masih dilestarikan. Untuk mempromosikan keberadaan tempat wisata agar diketahui oleh calon pengunjung, maka diperlukan peran komunikasi pemasaran. Salah satu bentuk komunikasi pemasaran merupakan bauran komunikasi pemasaran, yang terdiri dari; periklanan, penjualan personal, promosi penjualan, hubungan masyarakat dan publisitas, serta pemasaran langsung. (Kotler dan Armstrong 2008). Saat ini media antarpribadi (Words of Mouth) dapat dimasukkan sebagai salah satu media promosi yang dilakukan dengan sukarela dari orang yang pernah berkunjung.

Bauran komunikasi pemasaran tidak akan berjalan apabila tidak didukung oleh media komunikasi pemasaran. Berbeda dengan bauran pemasaran (price, place, promotion product), bauran komunikasi pemasaran menekankan pada upaya penyampaian informasi produk dengan memberikan pengetahuan, menarik minat, memiliki keinginan untuk membeli dan akhirnya terjadi tindakan untuk membeli. Tujuan utama dari kedu bauran tersebut berbeda. Pada bauran pemasaran pencapaian utama adalah mendapatkan profit sebesar-besarnya, berbeda dengan bauran komunikasi pemasaran yang bertujuan untuk menyampaikan informasi suatu produk.

Kampung Budaya Sindangbarang menggunakan upaya-upaya bauran komunikasi pemasaran untuk mempromosikan tempat wisatanya. Media-media komunikasi pemasaran digunakan untuk mempermudah masyarakat menggali informasi mengenai tempat pelestarian kebudayaan Sunda ini. Dalam penelitian ini terdapat tiga jenis media yang akan ditleiti, yaitu media leaflet, media hibrida (website dan Facebook), dan media antarpribadi (Words of Mouth) yang akan diukur efektivitas komunikasi pemasarannya melalui tiga aspek; 1) pengetahuan (kognitif), 2) afektif (perasaan), dan 3) konatif (tindakan). Media leaflet dan media hibrida merupakan media promosi resmi yang digunakan Kampung Budaya Sindangbarang, sedangkan media antarpribadi merupakan promosi dari mulut ke mulut pengunjung yang pernah mendatangi Kampung Budaya Sindangbarang sebelumnya.

Pengukuran efektivitas komunikasi pemasaran dari masing-masing media promosi merupakan kebaruan dalam penelitian ini. Sehingga, berdasarkan kajian literatur sebelumnya, maka perlu dilakukan penelitian mengenai Efektivitas Komunikasi Pemasaran tempat wisata yang berlokasi di Kampung Budaya Sindangbarang Desa Pasir Eurih, Kecamatan Taman Sari, Kabupaten Bogor.

Berdasarkan latar belakang yang dituliskan sebelumnya dapat dibangun beberapa masalah penelitian yang dapat dirumuskan oleh pertanyaan-pertanyaan berikut ini: 1) Bagaimana karakteristik pengunjung Kampung Budaya Sindangbarang? 2) Apa saja bentuk komunikasi pemasaran yang digunakan untuk menunjang kegiatan promosi Kampung Budaya Sindangbarang? 3) Bagaimana pengaruh antara bentuk komunikasi pemasaran yang dilakukan dengan efektivitas komunikasi pemasaran dilihat dari aspek kognitif, afektif, dan konatif?

Berdasarkan rumusan masalah diatas, tujuan penelitian dapat dipaparkan sebagai berikut; 1) Menganalisis efektivitas komunikasi pemasaran diukur dalam tiga aspek; aspek pengetahuan (kognitif), perasaan (afektif), tindakan (konatif). Efektivitas ini diukur pada tiga media promosi; leaflet, media hibrida (website dan Facebook), dan media antarpribadi (Words of Mouth) 2) Menganalisis unsur pesan AIDA media komunikasi pemasaran Kampung Budaya Sindangbarang dari masing-masing media promosi, ragam media yang paling banyak digunakan pengunjung untuk mengakses informasi Kampung Budaya Sindangbarang, serta frekuensi pengunjung mengakses media komunikasi pemasaran dalam satu bulan terakhir 3) Menganalisis pengaruh antara karakteristik pengunjung dan bentuk komunikasi pemasaran terhadap efektivitas komunikasi pemasaran.

\section{PENDEKATAN TEORITIS}

\section{Komunikasi Pemasaran}

Komunikasi pemasaran dapat diartikan sebagai aktivitas pemasaran yang berusaha menyebarkan informasi, mempengaruhi/membujuk, dan/atau mengingatkan pasar sasaran atas perusahaan dan produknya agar bersedia menerima, membeli, 
dan loyal pada produk yang ditawarkan perusahaan yang bersangkutan (Tjiptono 2008). Sedangkan menurut Kotler (2000) dalam Kusumastuti (2009) komunikasi pemasaran sebagai usaha untuk menyampaikan pesan kepada publik, terutama konsumen sasaran, mengenai keberadaan suatu produk di pasar.

\section{Efektivitas Komunikasi Pemasaran}

Efektivitas komunikasi pemasaran merupakan ukuran perubahan sikap konsumen seperti yang dipaparkan Engel dalam Hurriyati (2008), bahwa terdapat tiga komponen perubahan sikap yang ditujukan bagi konsumen. Efek kognitif dapat membentuk kesadaran informasi tertentu. Sedangkan afeksi dapat memberikan pengaruh untuk melakukan sesuatu, yaitu realisasi pembelian. Efek konatif atau perilaku merupakan pembentukan pola khalayak menjadi perilaku selanjutnya, yang diharapkan adalah pembelian ulang.

Menurut penelitian Agustina (2013) dan Aufa (2014) dampak aspek-aspek pesan dan karakteristik khalayak terhadap perubahan sikap dapat dilihat dari Awareness, Interest, Desire, dan Action (AIDA). AIDA merupakan suatu model komunikasi yang bersifat persuasif yang bertujuan untuk merangsang tindakan pembeli. Unsur pertama merupakan Awareness (perhatian) yaitu upaya mendapat perhatian konsumen (Rangkuti 2009). Unsur kedua merupakan interest (ketertarikan). Tahapan ini berupaya untuk menarik minat konsumen. Unsur ketiga merupakan desire (keinginan), yaitu tahapan membangkitkan keinginan. Effendy (1992) dalam Agustina (2013) menyatakan bahwa pada unsur ini produsen harus mampu memunculkan imbauan emosional (emotional appeal) sehingga pada tahap selanjutnya konsumen akan mengambil keputusan utnuk membeli produk yang ditawarkan produsen. Unsur terakhir merupakan action (tindakan). Action merupakan upaya yang menyebabkan tindakan.

\section{Bauran Komunikasi Pemasaran}

Pada hakikatnya promosi adalah suatu bentuk komunikasi pemasaran yang sering dikenal sebagai bauran komunikasi pemasaran atau bauran promosi. Bauran promosi merupakan instrumen dasar yang digunakan untuk mencapai tujuan komunikasi perusahaan, yang terdiri atas periklanan, penjualan personal, promosi penjualan, hubungan masyarakat dan publisitas, serta pemasaran langsung.

\section{Pariwisata dan Karakteristik Produk Wisata}

Pariwisata didefinisikan menurut UU No. 10 Tahun 2009 ialah berbagai macam kegiatan wisata dan didukung berbagai fasilitas serta layanan yang disediakan oleh masyarakat, pengusaha, pemerintah, dan pemerintah daerah. Dalam arti luas Damanik dan Weber (2006) menyatakan bahwa pariwisata adalah kegiatan rekreasi diluar domisili untuk melepaskan diri dari pekerjaan rutin atau mencari suasana lain.

Terdapat tiga elemen penawaran wisata yang sering disebut sebagai triple A's (Damanik dan Weber 2006), yang terdiri dari atraksi, aksesibilitas, dan amenitas. Atraksi merupakan objek wisata (baik yang bersifat tangible maupun intangible) yang memberikan kenikmatan kepada wisatawan. Atraksi terbagi atas tiga, yakni alam, budaya, dan buatan. Aksesibilitas mencakup keseluruhan infrastruktur transportasi yang menghubungkan wisatawan 'dari', 'ke', dan 'selama' didaerah tujuan wisata (Inskeep 1994 dalam Damanik dan Weber 2006). Sedangkan amenitas adalah infrastruktur yang sebenarnya tidak langsung terkait dengan pariwisata tetapi sering menjadi bagian dari kebutuhan wisatawan, seperti penjual buku panduan wisata, seni pertunjukkan, dll.

\section{Kerangka Penelitian}

Morrisan (2010) membagi karakteristik pengunjung berdasarkan tiga segmentasi; demografis, geografis, dan geodemografis. Segmentasi pasar pada dasarnya adalah suatu strategi untuk memahami struktur konsumen. Segmentasi demografis merupakan segmentasi konsumen berdasarkan demografi yang didasarkan pada kependudukan, misal; usia, jenis kelamin, besarnya anggota keluarga, pendidikan tinggi yang dicapai, jenis pekerjaan konsumen, tingkat penghasilan, agama, suku, dan sebagainya. Sedangkan segmentasi geografis merupakan pembagian khalayak berdasarkan jangkauan geografis. Pasar dibagi-bagi kedalam beberapa unit geografis yang berbeda yang mencakup suatu wilayah negara, provinsi, kabupaten, kota, hingga lingkungan perumahan yang dalam penelitian ini membagi wilayah Bogor dan sekitarnya, Jadetabek (Jakarta, Depok, Tangerang, Bekasi) dan Luar Jabodetabek 
(Jakarta, Bogor, Depok, Tangerang, Bekasi). Pada penelitian sebelumnya, Chairunisa (2013) menyatakan bahwa semakin tinggi tingkat pendidikan pengunjung maka semakin meningkat rasa keingintahuan mereka mengenai daya tarik wisata atau keunggulan yang dimiliki oleh suatu tempat wisata dan mencari-cari informasi dari berbagai media promosi. Pada variabel pengeluaran, Nourmaulina (2013) dalam penelitiannya membuktikan bahwa semakin tinggi rata-rata uang yang dikeluarkan pengunjung setiap bulan (pengeluaran), maka semakin banyak jumlah media komunikasi pemasaran yang diterima. Pengunjung dengan pengeluaran yang tinggi akan menggali informasi dari berbagai media komunikasi pemasaran untuk mengetahui harga, jenis, manfaat, dan informasi lainnya mengenai tempat wisata. Faktor internal dan eksternal turut berpengaruh positif pada keinginan wisatawan untuk melakukan kunjungan wisata (Hasan et al. 2012). Salah satu faktor internal adalah motivasi. Motivasi merupakan hal yang sangat mendasar dalam studi tentang wisatawan dan pariwisata, karena motivasi merupakan trigger dari proses perjalanan wisata (Wahab dan Sharpley 1994 dalam Damanik dan Weber 2006). Unsur pesan AIDA juga merupakan salah satu faktor penentu dalam efektivitas komunikasi pemasaran. Pada penelitian Nourmaulina (2013) menyatakan bahwa unsur pesan AIDA berpengaruh pada ketiga aspek efektivitas komunikasi pemasaran, yaitu pada aspek kognitif, afektif, dan konatif. Sehingga pada penelitian ini, variabel karakteristik pengunjung yang digunakan adalah usia, tingkat pendidikan, jenis pekerjaan, tingkat pengeluaran, motivasi, dan jangkauan geografis.

Berbagai upaya dilakukan agar produk wisata dapat diketahui oleh masyarakat, yaitu dengan melakukan berbagai bentuk komunikasi pemasaran yang terdiri dari Unsur pesan AIDA, ragam media yang digunakan, dan frekuensi penerimaan pesan. Menurut Kusumastuti (2009) agar pesan persuasif yang disampaikan dapat merangsang tindakan pembeli setidaknya harus memenuhi tahapan yang ada dalam karakteristik model komunikasi AIDA. Awareness merupakan upaya untuk mendapat perhatian, interest merupakan upaya untuk menarik minat konsumen, desire lebih berupaya untuk membangkitkan keinginan serta action lebih kepada upaya menyebabkan tindakan. Ragam media yang digunakan menurut penelitian sebelumnya, Wahyuni (2014) menyatakan bahwa untuk mempromosikan suatu tempat wisata media yang digunakan antara lain media internet, elektronik, ruang publik, dan word of mouth. Sementara itu pada penelitian Chairunnisa (2013), media promosi dibagi atas empat, yaitu media penyiaran, cetak, internet, dan word of mouth. Pada penelitian ini, ragam media yang digunakan meliputi media elektronik (televisi, radio), media hibrida (website, facebook), media luar ruang (billboard, spanduk), dan media antarpribadi (word of mouth).

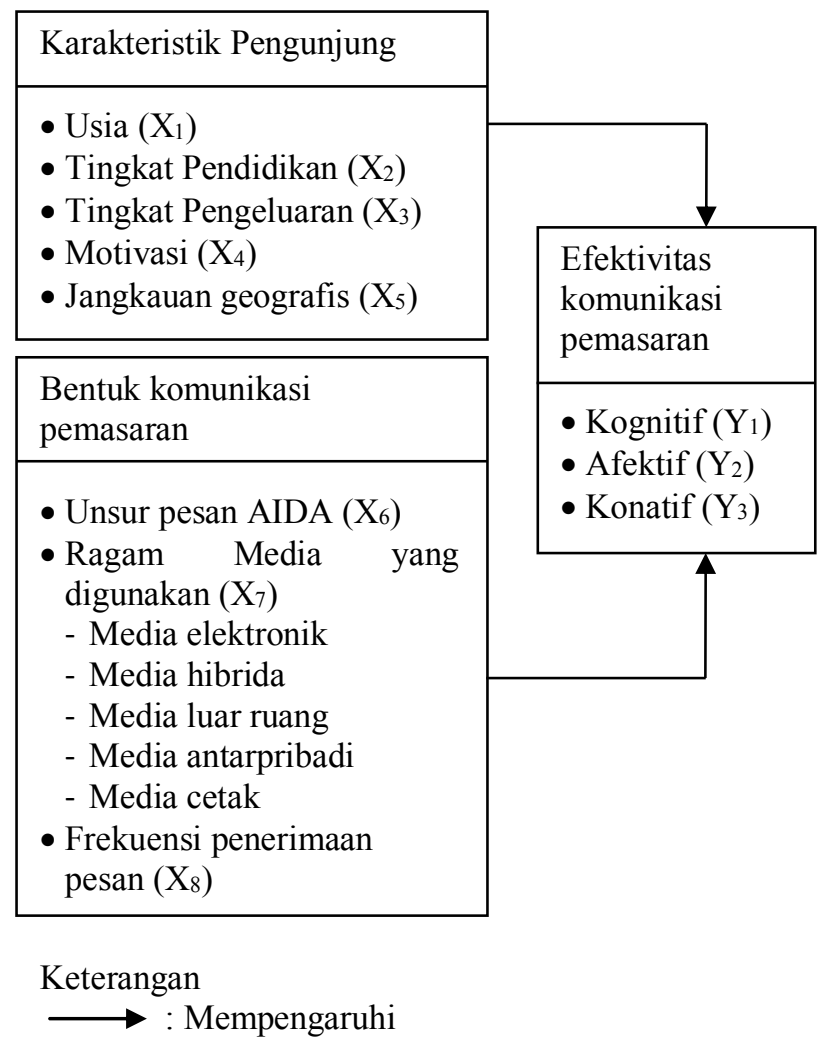

Gambar 1 Kerangka penelitian

Frekuensi penerimaan pesan merupakan variabel selanjutnya dalam bentuk komunikasi pemasaran. Frekuensi penerimaan pesan dalam setiap penelitian berbeda satu sama lain, tergantung pada time frame yang digunakan peneliti. Dalam penelitian Nourmaulina (2013), frekuensi pesan dikatakan tinggi dalam interval 9-12 kali akses dalam tiga bulan terakhir. Sementara itu Wahyuni (2014) dalam penelitiannya mengemukakan kategori sering dengan interval 5-6 kali dalam sebulan terakhir. Berdasarkan hasil penelitian Nourmaulina (2013) 
efektivitas komunikasi pemasaran dapat diukur pada aspek kognitif, afektif, dan konatif. Kognitif adalah pengetahuan terhadap produk atau perusahaan, afektif merupakan tingkat kesukaan atau ketertarikan terhadap suatu produk atau perusahaan, dan konatif adalah tingkat tingkah laku yang dimiliki terhadap perilaku pembelian suatu produk atau perusahaan.

\section{PENDEKATAN LAPANGAN}

\section{Lokasi dan Waktu}

Lokasi penelitian ini ialah di Kampung Budaya Sindangbarang, Desa Pasir Eurih, Kecamatan Taman Sari, Kabupaten Bogor. Penentuan lokasi untuk penelitian ini dilakukan secara sengaja (purposive). Penelitian ini dilaksanakan dari bulan Februari hingga Maret 2015.

\section{Teknik Pemilihan Rsponden dan Informan}

Pengambilan sampel responden pada penelitian ini adalah dengan menggunakan sensus. Sensus merupakan cara penelitian yang menyeluruh (seluruh elemen populasi) (Supranto 2007). Jumlah responden yang diambil dalam penelitian ini adalah seluruh pengunjung dewasa yang mengambil keputusan untuk berkunjung ke Kampung Budaya Sindangbarang dengan jumlah minimum pemilihan responden 30 orang dalam kurun waktu satu bulan terakhir. Pada informan, pemilihan informan dilakukan dengan cara purposive (sengaja), yaitu dengan staff pemasaran Kampung Budaya Sindangbarang.

\section{Teknik Pengumpulan Data}

Data yang digunakan dalam penelitian ini adalah data kuantitatif dan kualitatif. Data kuantitatif diperoleh dengan kuesioner, hal ini dimaksudkan agar peneliti mendapatkan informasi yang relevan dengan tujuan penelitian serta memperoleh informasi dengan reliabilitas dan validitas tinggi (Singarimbun dan Effendi 1989). Data kualitatif didapat dari wawancara mendalam dengan staff Kampung Budaya Sindangbarang untuk mengkaji tentang bentuk komunikasi pemasaran, seperti bauran promosi dan media apa yang digunakan sebagai media promosi Kampung Budaya Sindangbarang. Data kualitatif lain yang digunakan dalam penelitian ini diperoleh dari dokumen perusahaan, serta berbagai literatur yang relevan dengan penelitian ini, yaitu buku, jurnal penelitian, skripsi, thesis, dan artikel di internet.

\section{Teknik Pengolahan dan Analisis Data}

Data yang diperoleh dianalisis secara deskriptif, untuk menggambarkan efektivitas komunikasi pemasaran terhadap perubahan sikap pengunjung yang dilihat dari tiga aspek; kognitif, afektif, dan konatif. Data kuantitatif yang diperoleh dari kuesioner dengan dimasukkan dengan menggunakan program komputer Microsoft Excel 2007, kemudian dianalisis secara statistik deskriptif dan hasilnya dianalisis diinterpretasikan untuk memperoleh suatu kesimpulan. Sedangkan uji statistik analisis linear berganda digunakan untuk melihat pengaruh yang nyata antar variabel dengan data berbentuk interval. Pengolahan data dilakukan dengan menggunakan program komputer SPSS (Statistical Program for Social Sciences) for Windows version 20.0 dalam pengolahan data.

\section{HASIL DAN PEMBAHASAN}

\section{PROFIL PENGUNJUNG KAMPUNG BUDAYA SINDANGBARANG}

\section{Usia}

Karakteristik pengunjung berupa usia ini diperoleh dari sebaran normal data di lapang selama penelitian yang lalu dibagi menjadi tiga kategori; usia dewasa awal (20-28 tahun), usia pertengahan (29-37 tahun), dan usia tua (38-45 tahun). Berdasarkan data dilapang, didapatkan bahwa pengunjung paling banyak berasal dari kelompok usia dewasa awal (20-28 tahun) yaitu sebanyak 63.0 persen. Pada kelompok usia pertengahan (29-37 tahun) dan usia tua (38-45 tahun) yang masing-masing berjumlah 17.0 persen dan 20.0 persen. Pada kelompok umur ini biasanya berasal dari kalangan orangtua dan guru yang membawa anak atau murid-muridnya untuk belajar dan memahami kebudayaan sunda melalui permainan, kerajinan tangan, hingga tari tradisional yang dikemas berdasarkan paket wisata yang mereka pilih.

\section{Pendidikan}

Karakteristik pendidikan dikategorikan sesuai data yang didapat dilapang, yaitu SMA/Sederajat (12-14 tahun masa pendidikan), Diploma dan Strata 1 (15-16 tahun masa pendidikan), dan Strata 2 (17-18 tahun masa pendidikan. mayoritas pengunjung Kampung Budaya 
Sindangbarang berasal dari tingkat pendidikan diploma dan Strata 1 (S1) yang sebesar 50.0 persen. Adapun tingkat pendidikan SMA/sederajat sebesar 43.0 persen dan terakhir tingkat Strata 2 (S2) sebesar 7.0 persen. Hal ini dikarenakan pengunjung merupakan guru maupun orangtua yang mengantarkan anakanaknya pergi berwisata, selain itu pengunjung umumnya merupakan pekerja kantoran yang memanfaatkan waktu weekend untuk berlibur sejenak dengan mengunjungi Kampung Budaya Sindangbarang.

\section{Tingkat pengeluaran}

Pada penelitian ini, tingkat pengeluaran pengunjung Kampung Budaya Sindangbarang dibagi menjadi tiga kategori; rendah (Rp $800.000,00$ - Rp 3.200.000,00), sedang (Rp 3.200.001,00 - Rp 5.600.000,00), dan tinggi ( $R p$ 5.600.001,00 - Rp 8.000.000,00). Berdasarkan data yang diperoleh, pengunjung Kampung Budaya Sindangbarang didominasi oleh kategori pengeluaran rendah, yaitu sebanyak 57.0 persen. Adapun kategori sedang sebesar 33.0 persen dan kategori tinggi sebesar 10.0 persen. Pengunjung dengan kategori penghasilan rendah biasanya datang dari kalangan pelajar/mahasiswa yang memang berkunjung untuk melihat-lihat Kampung Budaya serta menjadikan bangunanbangunan uniknya sebagai objek foto.

\section{Motivasi}

Motivasi yang merupakan sesuatu yang dapat membuat seseorang bergerak atau melakukan suatu tindakan. Sehingga motivasi berkunjung adalah alasan seseorang untuk berkunjung ke Kampung Budaya Sindangbarang. Motivasi pada penelitian ini digolongkan menjadi tiga kategori, yaitu rendah pada rentang skor (1-2), sedang pada rentang skor (3-4), dan tinggi pada rentang skor (5-7). Berdasarkan data yang diperoleh di lapang, motivasi berkunjung ke Kampung Budaya Sindangbarang berada pada golongan rendah, yaitu sebesar 60.0 persen. Adapun golongan sedang dan tinggi hanya memperoleh masing-masing 30.0 persen dan 10.0 persen. Hal ini disebabkan karena kebanyakan pengunjung hanya mengetahui upacara adat tahunan yang diselenggarakan di Kampung Budaya Sindangbarang dan kesenian sundanya seperti atraksi tarian maupun silat sunda yang mereka kira diselenggarakan secara rutin, terutama setiap hari libur.

\section{Jangkauan geografis}

Jangkauan geografis adalah jarak antara tempat tinggal pengunjung dengan Kampung Budaya Sindangbarang. Pada penelitian ini, jangkauan geografis dibagi menjadi tiga golongan; rendah $(<53 \mathrm{~km})$, sedang $(53 \mathrm{~km}-84 \mathrm{~km})$, dan tinggi $(>84 \mathrm{~km})$. Pada golongan rendah jangkauannya adalah Kota Bogor dan sekitarnya, sedangkan untuk Jakarta, Depok, Tangerang, Bekasi (Jadetabek) termasuk dalam golongan sedang, dan pada golongan tinggi jangkauannya diluar Jakarta, Depok, Bogor, Tangerang, dan Bekasi.

Berdasarkan data yang diperoleh, dapat diketahui bahwa 43.0 persen pengunjung berasal dari wilayah Jadetabek atau golongan sedang. Adapun yang berasal dari Kota Bogor dan sekitarnya hanya berbeda tipis dengan Jadetabek (Jakarta, Depok, Tangerang, Bekasi), yaitu sebesar 40.0 persen. Sedangkan pengunjung yang berasal diluar Jabodetabek hanya 17.0 persen saja. Hal ini dikarenakan pengunjung banyak yang mengetahui mengenai Kampung Budaya Sindangbarang dari media internet dengan membaca website resmi maupun review orang lain yang ditulis melalui blog, sehingga pengunjung diluar Kota Bogor dan sekitarnya juga mengetahui mengenai keberadaan wisata Kampung Budaya Sindangbarang.

\section{BENTUK KOMUNIKASI PEMASARAN KAMPUNG BUDAYA SINDANGBARANG}

\section{Keragaman media}

Pada penelitian ini, keragaman media dibagi menjadi media elektronik (televisi dan radio), media hibrida (website, facebook, dan artikel atau laman blog orang lain), media luar ruang (penunjuk jalan dan billboard), media antarpribadi (keluarga dan teman), dan media cetak (leaflet, majalah dan koran). Berdasarkan data yang didapat dilapang, pengunjung mengetahui informasi lengkap mengenai Kampung Budaya Sindangbarang melalui media leaflet. Keseluruhan responden sebanyak 30 orang atau 100.0 persen mendapatkan leaflet oleh pihak pemasaran Kampung Budaya Sindangbarang. Ragam media yang kedua ialah Words of Mouth, sebanyak 21 orang/70.0 persen dari seluruh responden mendapatkan informasi mengenai Kampung Budaya Sindangbarang dari keluarga maupun teman. Adapun informasi yang didapat dari penunjuk jalan, artikel orang lain 
mengenai Kampung Budaya Sindangbarang, serta billboard memiliki jumlah masing-masing 20 orang/67.0 persen, 14 orang/47.0 persen, dan 12 orang $/ 40.0$ persen. Media website dan Facebook yang merupakan media promosi resmi Kampung Budaya Sindangbarang hanya dilihat oleh 10 orang/33.0 persen dan 5 orang/17.0 persen.

Selain keragaman media yang digunakan, pada penelitian ini juga meneliti mengenai tingkat keragaman media yang digunakan pengunjung dalam mengakses informasi mengenai Kampung Budaya Sindangbarang. Tingkat keragaman media yang digunakan oleh pengunjung terbagi atas tiga kategori; rendah (skor 12-16), sedang (skor 17-21), dan tinggi (skor 22-26). Seperti data yang ditunjukkan pada Tabel 10 tingkat keragaman media yang digunakan oleh pengunjung adalah sedang, yaitu sebesar 83.0 persen. Adapun pada kategori rendah dan tinggi masing-masing hanya sebesar 10.0 persen dan 7.0 persen dari total 30 responden. Hal ini dikarenakan banyak pengunjung yang mengetahui Kampung Budaya Sindangbarang melalui media internet dan antarpribadi. Tidak banyak pegunjung yang tahu bahwa beberapa stasiun televisi dan radio menyiarkan mengenai Kampung Budaya Sindangbarang dalam salah satu programnya

\section{Frekuensi penerimaan pesan}

Data frekuensi penerimaan pesan dibagi berdasarkan keadaan dilapang, lalu diperoleh tiga kategori; rendah (3-6 kali/bulan), sedang (7-10 kali/bulan), dan tinggi (11-14/bulan). Berdasarkan data di lapang dapat diketahui bahwa sebesar 57.0 persen pengunjung termasuk dalam kategori rendah dalam frekuensi penerimaan pesan. Setelah pengunjung mendapatkan rekomendasi dari teman maupun keluarga, biasanya mereka mencari tahu lewat internet guna menambah informasi serta mencari alamat Kampung Budaya Sindangbarang. Hal tersebut menjadi alasan mengapa tidak banyak jumlah pengaksesan informasi oleh pengunjung dalam satu bulan.

\section{UNSUR PESAN AIDA (AWARENESS, INTEREST, DESIRE, DAN ACTION)}

Unsur pesan merupakan unsur dalam suatu media promosi yang didalamnya memperhatikan isi pesan. Unsur pesan diukur berdasarkan
AIDA, yaitu Awareness yaitu suatu bentuk upaya untuk mendapatkan perhatian konsumen, Interest merupakan unsur pesan sebagai bentuk upaya untuk menarik perhatian konsumen, Desire merupakan unsur pesan sebagai bentuk upaya untuk membangkitkan keinginan konsumen, dan Action yaitu realisasi tindakan. Setiap responden dalam pertanyaan bagian ini boleh memilih lebih dari satu media, tergantung media apa yang mereka gunakan untuk mengakses informasi mengenai Kampung Budaya Sindangbarang. Unsur Pesan AIDA pada masing-masing media dalam penelitian ini dibagi atas tiga kategori; tinggi, sedang, dan rendah.

Media pertama yang diukur oleh unsur AIDA adalah leaflet. Leaflet merupakan salah satu media komunikasi pemasaran berupa cetak dan dipergunakan untuk mempresentasikan perusahaan. Pada media ini diketahui bahwa unsur Awareness, Interest, Desire adalah tinggi. Pengunjung merasa mendapatkan gambaran informasi mengenai tempat wisata, baik informasi umum, macam kegiatan wisata, dan gambar-gambar kegiatan wisata melalui leaflet. Pengunjung mendapatkan media leaflet saat datang berkunjung ke tempat wisata ini sekaligus mendapatkan penjelasan langsung dari staff Kampung Budaya Sindangbarang, sehingga jumlah responden yang mengakses leaflet ini adalah sebesar 30 orang. Sedangkan, pada unsur action ternyata adalah sedang, yang berarti bahwa setelah pengunjung melakukan tindakan berupa kunjungan, setelah melihat media promosi ini lantas tidak membuat pengunjung ingin mengikuti salah satu kegiatan wisata yang ditawarkan. Salah satu faktornya adalah karena tarif harga wisatanya cukup mahal.

Media kedua adalah media hibrida yang terdiri dari website dan facebook. Responden yang mengakses media ini berjumlah 15 orang. Pada media ini keempat unsur pesan; Awareness, Interest, Desire, dan Action sama-sama berada pada kategori sedang. Walaupun website dan facebook memiliki lebih banyak fitur untuk mencantumkan informasi dan gambar-gambar kegiatan wisata, namun orang-orang merasa harus berkunjung langsung ke Kampung Budaya Sindangbarang untuk memastikan keadaan wisata secara langsung sebelum memutuskan paket wisata mana yang akan dipilih. Media yang terakhir adalah media antarpribadi atau Words of Mouth. Responden yang mengetahui Kampung 
Budaya Sindangbarang melalui media antarpribadi berjumlah 26 orang. Pada media ini komunikasi ini terjadi antara orang yang sudah pernah mengunjungi Kampung Budaya Sindangbarang dengan orang yang belum pernah berkunjung. Persebaran informasi ini dapat terjadi secara langsung tatap muka maupun melalui sosial media. Sesuai data yang diperoleh di lapang, media antarpribadi ini ternyata mampu membuat Action atau tindakan pengunjung untuk datang dan berwisata berada pada kategori tinggi. Pengunjung sebagian besar sangat tertarik dengan suasana alam dan bangunan khas adat sunda yang ada di Kampung Budaya Sindangbarang sehingga mereka akan merekomendasikan Kampung Budaya Sindangbarang sebagai tempat wisata budaya sunda kepada orang lain. Rekomendasi tersebut dilakukan baik dengan lisan maupun media sosial. Setelah mengambil gambar dengan latar tempat wisata, pengunjung cenderung akan mengunduh gambar tersebut ke media sosial yang mereka miliki. Sementara ketiga unsur sebelumnya; Awareness, Interest dan Desire hanya berada pada kategori sedang.

Dari ketiga media yang dijelaskan sebelumnya, pengunjung mengakui bahwa media antarpribadi atau Words of Mouth merupakan media yang paling kuat dalam mempengaruhi keputusan berkunjung mereka ke Kampung Budaya Sindangbarang. Hal ini karena pemasaran viral bersifat eksponensial. Safko (2010) menyatakan bahwa pembeli yang tidak senang dengan suau produk maupun pelayanannya akan menyebarkan kepada 20 orang tentang pengalaman buruknya secara langsung. Sosial media membuat hal tersebut dapat menjadi berlipat ganda, dari 20.000 hingga 200.000 orang.

\section{EFEKTIVITAS KOMUNIKASI PEMASARAN}

\section{Kognitif}

Aspek kognitif mengukur seberapa jauh pengetahuan pengunjung mengenai Kampung Budaya Sindangbarang. Berdasarkan data yang diperoleh, aspek pengetahuan atau kognitif pengunjung tergolong rendah. Dari total 30 orang, terdapat 14 orang/47.0 persen yang tidak mengetahui informasi secara umum mengenai Kampung Budaya Sindangbarang setelah melihat media promosi. Pengunjung mengaku kesulitan mengingat nama paket wisata serta nama bangunan karena menggunakan istilah dan bahasa sunda. Upacara adat tahunan yang secara rutin diadakan di kampung budaya juga hanya diketahui oleh pengunjung pada usia dewasa awal (20-28 tahun) karena pada kelompok usia tersebut umumnya memiliki rasa keingintahuan tinggi pada acara-acara kebudayaan. Sedangkan, pada kelompok usia pertengahan dan tua biasaanya mengunjungi Kampung Budaya Sindangbarang karena mengantarkan murid atau anak-anaknya berwisata.

\section{Afektif}

Aspek afektif digunakan untuk mengukur emosi, keinginan, dan rasa suka pengunjung kepada Kampung Budaya Sindangbarang. Setelah melihat alat promosi, kebanyakan pengunjung menyukai paket wisata dan fasilitas yang ditawarkan, sehingga berdasarkan data dilapang diketahui bahwa sebanyak 22 orang/73.0 persen memiliki aspek afektif yang tinggi. Hal ini karena wisata Kampung Budaya Sindangbarang menawarkan konsep wisata yang tidak banyak ditemukan di tempat wisata lainnya, yaitu memasukkan unsur-unsur budaya sunda dalam kegiatan wisatanya.

\section{Konatif}

Aspek konatif merupakan aspek yang berkenaan dengan tindakan seseorang untuk mengunjungi Kampung Budaya Sindangbarang. Berdasarkan data di lapang diketahui bahwa aspek tindakan atau konatif pengunjung berada pada kategori tinggi, yaitu sebesar 17 orang/57.0 persen. Para pengunjung mengaku akan mengunjungi kembali Kampung Budaya Sindangbarang serta merekomendasikan kepada teman maupun keluarga. Pengunjung juga tertarik akan menggunakan paket wisata yang ditawarkan oleh kampung budaya, terutama untuk guru atau orangtua yang membawa anak-anaknya berwisata. Sedangkan untuk pengunjung yang datang tidak dengan rombongan juga tertarik mengikuti paket wisata yang ditawarkan, namun karena keterbatasan peserta, mereka tidak dapat mengikuti kegiatan wisata. Namun, mereka akan mengajak keluarga maupun teman untuk mengunjungi kembali Kampung Budaya Sindangbarang dan mengikuti kegiatan wisata 


\section{PEUBAH-PEUBAH YANG MEMPENGARUHI EFEKTIVITAS KOMUNIKASI PEMASARAN}

Uji statistik linear berganda digunakan untuk mengetahui pengaruh peubah pada karakteristik pengunjung (usia, tingkat pendidikan, tingkat pengeluaran, motivasi, jangkauan geografis) dan bentuk komunikasi pemasaran (unsur pesan AIDA, ragam media dan frekuensi penerimaan pesan) terhadap efektivitas komunikasi pemasaran yang diukur dalam tiga aspek; aspek kognitif, afektif, dan konatif.

\section{Leaflet}

Media leaflet hanya berpengaruh pada aspek perasaan atau afektif saja. Peubah yang mempengaruhi adalah peubah usia dan unsur pesan AIDA. Pada peubah usia, aspek perasaan maupun rasa ketertarikan pengunjung terhadap Kampung Budaya Sindangbarang setelah melihat leaflet ditentukan oleh usia tertentu. Pengunjung dengan kategori usia pertengahan maupun usia tua menganggap wisata edukasi Kampung Budaya Sindangbarang sangat baik untuk media pembelajaran budaya anak-anak. Hal tersebut didukung dengan penjelasan dari pihak Kampung Budaya Sindangbarang yang memfasilitasi pertanyaan langsung dari pengunjung. Peubah selanjutnya yaitu unsur pesan AIDA dalam leaflet yang juga berpengaruh positif dalam aspek afektif. Pengunjung mengakui bahwa informasi yang tertera pada leaflet, baik dari segi kelengkapan informasi paket wisata dan gambar kegiatan wisata dapat mempengaruhi ketertarikan dan rasa suka pengunjung terhadap wisata Kampung Budaya Sindangbarang. Untuk menimbulkan emosi dan keterarikan pengunjung, maka informasi pada leaflet harus didukung dengan ukuran huruf sesuai dengan ukuran kertas leaflet, perpaduan warna pada background, serta keteraturan penyusunan informasi sehingga pengunjung dapat menerima pesan dengan baik.

\section{Media hibrida}

Seperti media leaflet, media hibrida hanya berpengaruh pada aspek perasaan atau afektif saja. Peubah yang mempengaruhi ialah peubah usia dan unsur pesan AIDA. Pada peubah usia, aspek perasaan maupun rasa ketertarikan pengunjung terhadap Kampung Budaya
Sindangbarang setelah melihat leaflet ditentukan oleh usia tertentu Pengunjung dengan kategori usia pertengahan (29-37 tahun) maupun tinggi (38-45 tahun) tertarik untuk mengikuti salah satu paket wisata karena mereka menganggap Kampung Budaya Sindangbarang ini dianggap sebagai salah satu media pembelajaran budaya yang saat ini sudah mulai dilupakan oleh orangorang modern namun dikemas menjadi sebuah paket wisata yang menyenangkan. Sedangkan pada peubah unsur pesan AIDA, pengunjung mengaku bahwa informasi yang tertera pada website maupun facebook, baik dari segi kelengkapan informasi mengenai sejarah, budaya sunda, hingga fasilitas di Kampung Budaya Sindangbarang disajikan dengan bahasa persuasif serta didukung dengan gambar-gambar kegiatan wisata. Terdapat perbedaan antara media promosi website dan facebook. Pada website, penataan informasi, gambar, dan kolom testimoni pengunjung lebih teratur serta didukung dengan desain dan warna website. Adapun kelebihan ada facebook, yaitu isi informasi yang lebih sering diperbaharui.

\section{Media antarpribadi (Words of Mouth)}

Media antarpribadi hanya berpengaruh pada peubah tingkat pengeluaran saja. Tingkat pengeluaran pengunjung menjadi faktor penentu pada rasa suka dan ketertarikan mengenai Kampung Budaya Sindangbarang. Pengunjung dengan kategori tingkat pengeluaran rendah ( $\mathrm{Rp}$ 3.200.000,00) cenderung menyukai wisata Kampung Budaya Sindangbarang walaupun mereka merasa bahwa harga paket wisata yang ditawarkan cukup mahal dan lebih memilih untuk melihat dan berfoto-foto saja. Pada kategori pengeluaran sedang, yaitu (Rp 3.200.001,00 - Rp 5.600.000,00), dan tinggi (Rp 5.600.001,00 - Rp 8.000.000,00) tertarik untuk mengikuti salah satu paket wisata karena mereka umumnya sudah berkeluarga dan mengajak anak-anak atau kunjungan dengan sekolah. tertarik untuk mengikuti paket wisatanya karena harganya yang cukup mahal.

\section{KESIMPULAN DAN SARAN}

\section{Kesimpulan}

Pada media leaflet mempengaruhi karakteristik pengunjung berupa usia dan unsur pesan AIDA pada aspek perasaan atau afektif. Hal ini juga terjadi pada media hibrida. Pada media hibrida 
terjadi pengaruh pada peubah usia dan unsur pesan AIDA dalam aspek afektif. Media terakhir, yaitu Words of Mouth hanya berpengaruh pada satu peubah, yaitu tingkat pengeluaran dalam aspek afektif.

Kampung Budaya Sindangbarang merupakan tempat wisata edukasi budaya Sunda yang terletak di Kabupaten Bogor. Tempat wisata ini cukup banyak diminati wisatawan karena selain memiliki paket wisata yang edukatif serta lokasinya masih berada di wilayah Jabodetabek. Usia pengunjung yang mengunjungi Kampung Budaya Sindangbarang merupakan penduduk dari usia dewasa awal (20-28 tahun), sehingga jenjang pendidikan terakhir pengunjung umumnya adalah D3/S1 dengan kategori pengeluaran rendah ( $\mathrm{Rp} \quad 800.000,00$ Rp3.200.000,00). Motivasi pengunjung tergolong rendah (1-2 motivasi) dengan motivasi yang paling banyak diminati penunjung adalah rekreasi.

Ragam media promosi yang digunakan oleh Kampung Budaya Sindangbarang adalah leaflet, website, facebook, dan media luar ruang seperti billboard dan papan penunjuk jalan. Keseluruhan media promosi tersebut tidak kuat berpengaruh terhadap kepututsan berkunjung dibandingkan media antarpribadi, yang meliputi Words of Mouth dan referensi orang lain melalui artikel dan laman blog orang lain.

Desain unsur pesan AIDA (Awareness, Interest, Desire, dan Action) diukur pada tiga media; leaflet, media hibrida (website dan Facebook) dan media antarpribadi (Words of Mouth). Unsur pesan AIDA pada masing-masing media saling melengkapi dan telah mencapai unsur tindakan (action) atau untuk mengunjungi dan menggunakan paket wisata Kampung Budaya Sindangbarang. Media leaflet dan media hibrida mampu membuat pengunjung tertarik dan ingin mengikuti salah satu kegiatan wisatanya. Sedangkan, media Words of Mouth yang didapat dari rekomendasi orang lain ternyata paling mencapai unsur tindakan dari pengunjung.

\section{Saran}

Media leaflet dan hibrida memiliki peran yang baik sebagai media penyampai informasi umum kepada masyarakat mengenai wisata Kampung Budaya Sindangbarang. Namun, pengunjung Kampung Budaya Sindangbarang umumnya melakukan survei terlebih dahulu sebelum melakukan wisata sehingga peningkatan pelayanan dari staff pemasaran adalah penting. Hal ini karena komunikasi pemasaran merupakan kegiatan yang terintegrasi dari berbagai elemen, salah satunya adalah penjualan personal.

Peningkatan pelayanan yang baik tentu akan membuat pengunjung puas dan akan memberikan tanggapan yang baik. Apabila pengunjung merasa puas dengan wisata dan pelayanan yang diberikann, maka pengunjung memungkinkan untuk melakukan rekomendasi kepada orang lain, baik secara tatap muka maupun melalui media sosial pribadi yang dimilikinya. Pemasaran viral ini bersifat eksponensial. Safko (2010) menyatakan bahwa "Pembeli yang tidak senang dengan suau produk maupun pelayanannya akan menyebarkan kepada 20 orang tentang pengalaman buruknya secara langsung. Sosial media membuat hal tersebut dapat menjadi berlipat ganda, dari 20.000 hingga 200.000 orang".

\section{DAFTAR PUSTAKA}

Aufa J. 2014. Efektivitas website sebagai media komunikasi pemasaran Kampoeng Wisata Bisnis Tegalwaru, Ciampea, Bogor, Jawa Barat. [Skripsi]. Bogor (ID): Institut Pertanian Bogor.

Agustina L. 2013. Efektivitas komunikasi pemasaran produk olahan pertanian Institut Pertanian Bogor di Serambi Botani, Mal Gandaria City. [Skripsi]. Bogor (ID): Instut Pertanian Bogor.

Damanik J., Weber H. 2006. Perencanaan ekowisata dari teori ke aplikasi. Yogyakarta (ID): ANDI Yogyakarta dan PUSPAR UGM. 135 hal.

Hurriyati R. 2008. Bauran pemasaran dan loyalitas konsumen. Bandung (ID): CV Alfabeta.186 hal

Kusumastuti YI. 2009. Komunikasi Bisnis. Bogor [ID]: IPB Press. 201 hal.

Rangkuti F. 2009. Strategi promosi yang kreatif dan analisis kasus integrated marketing communication. Jakarta (ID): Prenada Media. 448 hal.

Safko L. 2010. The social media bible. Ed ke-2. New Jersey (USA): John Wiley and Sons Inc. 743 hal.

Tjiptono F. 2008 Strategi Pemasaran. Ed ke-3. Yogyakarta (ID).: ANDI Yogyakarta. 587 hal. 